\title{
仕上材の二酸化炭素透過性と透 INFLUENCE OF CARBON DIOXIDE 湿性がコンクリートの中性化へ AND MOISTURE PERMEABILITY 与える影響 OF COATING MATERIALS ON CARBONATION OF CONCRETE
}

川村康晴— $* 1$ 本橋健司— $* 2$

キーワード :

塗料, 仕上塗材, 二酸化炭素透過性, 透湿性, 促進中性化試験

Keywords:

Paints, Coating materials, Carbon dioxide permeability, Moisture permeability, Accelerated carbonation test

\section{Yasuharu KAWAMURA $-* 1 \quad$ Kenji MOTOHASHI- $* 2$}

Influence of carbon dioxide permeability and moisture permeability of coating materials on carbonation depth of substrate concrete was discussed by 2 series of accelerated carbonation tests. Moisture permeability shows higher correlation than carbon dioxide permeability. Accordingly, moisture change in concrete was monitored in accelerated carbonation test in this study. It was found that water generated by carbonation reaction of concrete raise moisture content of the substrate concrete. Consequently, this increase of moisture content strongly affects the carbonation depths of concrete.

In conclusion, moisture permeability has high correlation between carbonation depth, and which is due to generation of water by carbonation reaction in the accelerated carbonation test.

\section{1. はじめに}

塗料及び建築用仕上塗材 (以下、仕上材) の製品は多種・多様あり、 それぞれの材料規格・分類における中性化抑制効果の評価が不十分 な現状では、製品ごとの中性化抑制効果の評価が必要である。

これまでにも仕上材の中性化抑制効果を効率的に評価する方法 は種々検討されている。コンクリートの促進中性化試験に準じた方

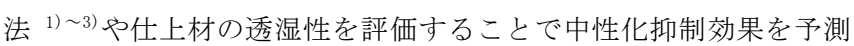
する方法 ${ }^{4)}$,5) な゙が報告されている。

筆者らは、仕上材の中性化抑制効果を予測するため、コンクリー 卜の中性化に直接影響を与えるであろう、仕上材の二酸化炭素 (以下 $\mathrm{CO}_{2}$ ) 透過性の評価方法を検討してきた。短期間でかつ多様な形状の 材料を評価できる方法としてボックス法の提案を行っている ${ }^{6)}$ 。

既往の報告では、中性化抑制効果は仕上材の透気性、透湿性 ${ }^{4), 7)}$ との相関が指摘されているが、 $\mathrm{CO}_{2}$ 透過性との相関を確認した報告例 は少ない。

本報では、2シリーズ行った促進中性化試験の検討結果を報告す る。シリーズ 1 として、仕上材の $\mathrm{CO}_{2}$ 透過性及び透湿性がコンクリ 一トの促進中性化試験における仕上材の中性化抑制効果一与える影 響を確認した。検討の結果、中性化の抑制効果は仕上材の透湿性の 影響を受けることが確認された。そこで、シリーズ 2 として、再度、 促進試験中のコンクリートの含水率変化に着目し実験を行った。仕 上材の透湿性とコンクリートの含水率との関係を明確にし、仕上材 の透湿性及び二酸化炭素透過性がコンクリートの中性化に与える影 響について報告する。

\section{2. 試験概要}

\section{1 試験体}

促進中性化試験は、水セメント比 $65 \%$ のコンクリートを下地とし て用いた。試験体は JIS A 1153 に規定される方法で打設、脱型を行 い、材齢 4 週まで水中養生を行った。次いで、相対湿度 $60 \pm 5 \%$ 、温 度 $20 \pm 2{ }^{\circ} \mathrm{C}$ で材齢 8 週まで気中養生した。調合及び性状と使用材料 を表 1 、表 2 に示す。

その後、コンクリートの側型枠面に、JIS A 6916 に規定される下 地調整叙材 C- 1 で穴埋め処理を行い 1 週間の養生後、仕上材を施工 した。評価を行った仕上材材料は、JIS K 5660 に規定される塗料と、 JIS A 6909 の建築用仕上塗材に規定される薄付け仕上塗材と複層仕 上塗材の中から表 3 に示寸仕上材を選択した。

\begin{tabular}{|c|c|c|c|c|c|c|c|c|}
\hline \multirow{2}{*}{$\begin{array}{c}\text { 実験 } \\
\text { シリーズ }\end{array}$} & \multirow{2}{*}{$\begin{array}{l}\text { W/C } \\
(\%)\end{array}$} & \multirow{2}{*}{$\begin{array}{l}\mathrm{S} / \mathrm{a} \\
(\%)\end{array}$} & \multicolumn{4}{|c|}{ 单位量 $\left(\mathrm{kg} / \mathrm{m}^{3}\right)$} & \multirow{2}{*}{$\begin{array}{c}\text { 空気量 } \\
(\%)\end{array}$} & \multirow{2}{*}{$\begin{array}{l}\text { スランフ } \\
\left(\mathrm{cm}^{2}\right)\end{array}$} \\
\hline & & & C & W & G & $\mathrm{S}$ & & \\
\hline 1 & \multirow{2}{*}{65} & \multirow{2}{*}{46.4} & \multirow{2}{*}{274} & \multirow{2}{*}{178} & \multirow{2}{*}{968} & \multirow{2}{*}{829} & 4.6 & 20 \\
\hline 2 & & & & & & & 4.6 & 19 \\
\hline
\end{tabular}

\section{表 2 使用材料}

\begin{tabular}{|c|c|c|}
\hline 材料 & 記号 & 仕様 \\
\hline セメント & C & 太平洋セメント社製普通ポルトランドセメン(密度: $\left.3.16 \mathrm{~g} / \mathrm{cm}^{3}\right)$ \\
\hline 水 & W & 上水道水 \\
\hline 粗骨材 & G & $\begin{array}{l}\text { 茨城県桜川市産硬質砂岩砕石 } \\
\text { (表乾密度: } 2.64 \mathrm{~g} / \mathrm{cm}^{3} \text { 、吸水率:0.68\%、粗粒率(F.M.): } 6.80 \text { ) }\end{array}$ \\
\hline 細骨材 & $\mathrm{s}$ & $\begin{array}{l}\text { 静岡県掛川市産陸砂 } \\
\text { (表乾密度:2.58 } \mathrm{g} / \mathrm{cm}^{3} \text { 、吸水率:1.81\%, 粗粒率(F.M.):2.97) }\end{array}$ \\
\hline
\end{tabular}

\footnotetext{
General Purpose Coating Dept., Kikusui Chemical Industries Co., Ltd.

2 Prof., Graduate School of Engineering, Shibaura Institute of Technology, Dr. Eng.
} 
表 3 仕上材の種類一覧

\begin{tabular}{|c|c|c|}
\hline 試験体略称 & 仕上材の種類 & 表面形状 \\
\hline 薄塗E-1 & 外装薄塗材 $\mathrm{E}$ & 砂壁状(リシン) \\
\hline 薄塗E-2 & 外装薄塗材 $\mathrm{E}$ & 石材調（着色骨材系） \\
\hline 薄塗E-3 & 外装薄塗材E & 平たん状（ローラーリシン） \\
\hline 可とう薄E & 可とう形外装薄塗材 $E$ & 砂壁状 \\
\hline 防薄E & 防水形外装薄塗材 $\mathrm{E}$ & 平たん状 \\
\hline 複層E & 複層塗材 $\mathrm{E}$ & 平たん状 \\
\hline 可とう複CE & 可とう形複層塗材CE & 平たん状 \\
\hline 防複E & $\begin{array}{c}\text { 防水形複層塗材 } \mathrm{E} \\
\end{array}$ & 平たん状 \\
\hline 塗料 & つや有りアクリルエマルションペイント & 平滑 \\
\hline
\end{tabular}
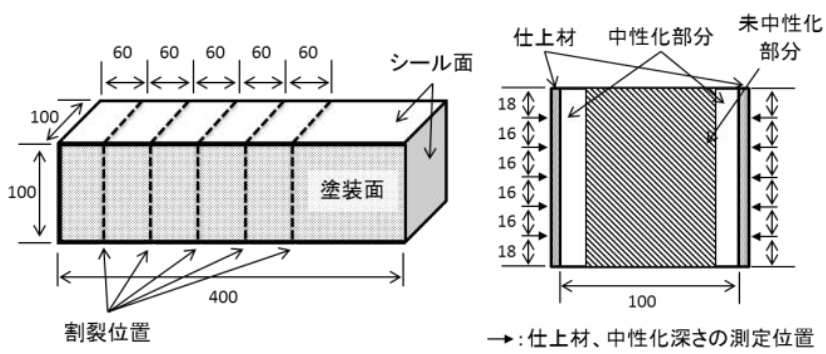

図 1 中性化深さの測定位置

仕上材は、JASS18 及び JASS23 に準拠して施工した。仕上材の施 工後 2 週間養生した後、無塗装面にアルミテープを貼り付け試験に 供した。

\section{2 促進中性化試験}

JIS A 1153 に準じて促進中性化試験を行い、材齢 1 週、2 週、4 週、8 週、13 週、26 週での中性化深さを測定した。中性化深さはJIS A 1152 に準拠して測定し、図 3 に示寸 2 面 10 力所の平均值を求め た。また、中性化深さと同じ測定位置で仕上材の塗膜厚みも測定を 行った。

本検討の中で促進試験のシリーズ 2 においては、コンクリートの 含水率変化についても測定を行った。

含水率の測定方法は、中性化深さ測定後の割裂した試験体を $100^{\circ} \mathrm{C}$ の恒温槽で乾燥させた。試験体の重量変化を測定し恒量となる まで乾燥させた。その前後の試験体重量の減量分をコンクリートの 含水率とした。

\section{3. 試験結果と考察}

\section{3. $1 \mathrm{CO}_{2}$ 透過性及び透湿性と中性化抑制効果の関係}

\section{(1) 中性化抑制効果の確認}

$\mathrm{CO}_{2}$ 透過性及び透湿性と中性化抑制効果の関係を確認するため、ま ずは、シリーズ 1 として仕上材を施工したコンクリートの促進中性 化試験を行った。

促進中性化試験における各材齢での中性深さの測定結果と仕上材 の厚みを表 4 に示す。また、中性化深さの経時変化を図 2 に示す。 一部の仕上材で測定值にばらつきがみられるが、中性化深さと促進 期間の間にいわゆる $\mathrm{t}$ 則の関係性が確認出来た。そこで最小 2 乗 法により各試験体の中性化速度係数を求め、ブランクとの速度係数 の比から中性化率を求めた。結果を表 5 に示寸。また、JASS5 に記 載されている種類別の中性化率の值 ${ }^{8)}$ 及び前報 ${ }^{6}$ における各仕上材 料の $\mathrm{CO}_{2}$ 透過度と透湿度も併せて示す。

今回、実施した促進中性化試験の中性化率は文献值よりもかなり
低い。但し、外装薄塗材 $\mathrm{E}$ が高く、次いで可とう形薄塗材 E、防水 形薄塗材 E と中性化率が低くなるなど全体的には類似した傾向が確 認出来る。一方で、JIS 上の分類では同じ外装薄塗材 E の中でも、 中性化率が異なることが確認出来た。薄塗 E-1のいわゆるリシンと、 薄塗 E-3 のローラーリシンでは中性化率が倍も違うことが分かる。

\section{(2) $\mathrm{CO}_{2}$ 透過性及び透湿性と中性化率との関係}

前報 ${ }^{6)}$ で求めている $\mathrm{CO}_{2}$ 透過度と中性化率との関係を図 3 に、透 湿度と中性化率との関係を図 4 示す。それぞれ決定係数は、 $\mathrm{CO}_{2}$ 透過 度の 0.4 に対し透湿度は 0.84 と強い正の相関を示す。コンクリート の中性化に直接的に働く、 $\mathrm{CO}_{2}$ の透過性より透湿性の方が中性化率と の相関性を見せる。

表 4 促進中性化試験の測定結果（シリーズ 1)

\begin{tabular}{|c|c|c|c|c|c|c|c|c|}
\hline \multirow{2}{*}{ 試験体略称 } & \multirow{2}{*}{$\begin{array}{c}\text { 平均膜厚 } \\
(\mathrm{mm})\end{array}$} & \multicolumn{6}{|c|}{ 中性化深さ (mm) } & \multirow{2}{*}{$\begin{array}{c}\text { 速度係数 } \\
\left(\mathrm{mm} / \text { 週 }^{1 / 2}\right)\end{array}$} \\
\hline & & 1週 & 2週 & 4週 & 8週 & 13週 & 26週 & \\
\hline 薄塗E-1 & 0.7 & 1.9 & 2.8 & 3.9 & 4.6 & 9.7 & 13.0 & 2.38 \\
\hline 薄塗E-2 & 1.3 & 1.6 & 1.7 & 2.6 & 2.6 & 4.8 & 7.7 & 1.35 \\
\hline 薄塗E-3 & 0.5 & 1.1 & 1.4 & 2.6 & 2.6 & 4.0 & 6.1 & 1.13 \\
\hline 可とう薄E & 0.8 & 1.2 & 1.2 & 1.7 & 1.6 & 3.0 & 4.7 & 0.84 \\
\hline 防薄E & 0.5 & 1.2 & 1.4 & 1.3 & 1.0 & 1.8 & 2.2 & 0.49 \\
\hline 複層E & 0.7 & 1.4 & 1.8 & 2.2 & 1.9 & 4.3 & 7.6 & 1.26 \\
\hline 可とう複CE & 0.8 & 1.1 & 0.9 & 1.2 & 1.5 & 2.0 & 2.9 & 0.57 \\
\hline 防複E & 0.6 & 0.8 & 0.9 & 1.4 & 1.5 & 1.9 & 2.3 & 0.52 \\
\hline 塗料 & 0.1 & 1.2 & 1.3 & 1.7 & 1.9 & 2.7 & 3.6 & 0.74 \\
\hline ブランク & - & 7.1 & 8.4 & 11.5 & 14.0 & 17.9 & 22.9 & 4.87 \\
\hline
\end{tabular}
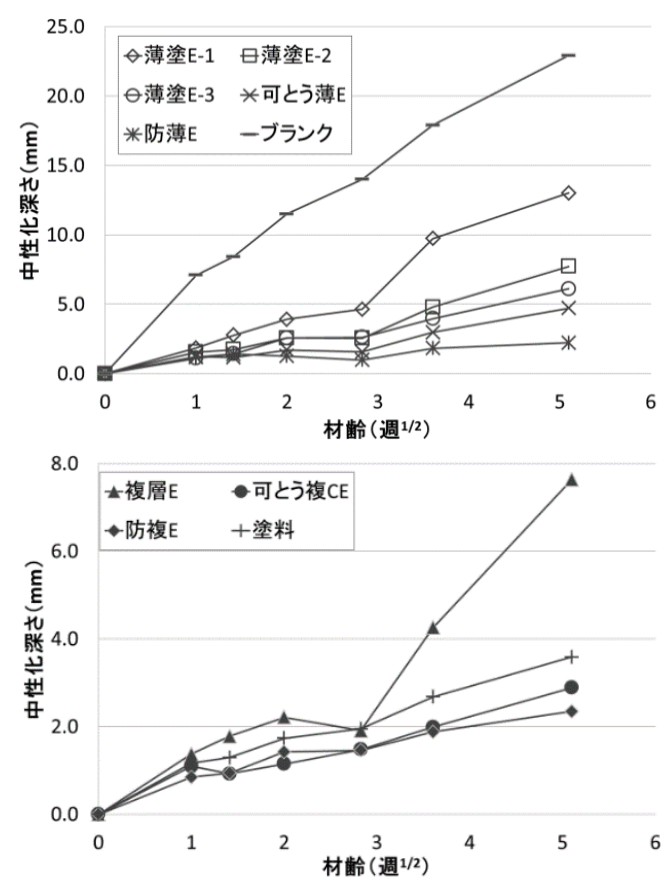

図 2 中性化深さの径時変化（シリーズ1)

\section{表 5 各試験体の中性化率及び $\mathrm{CO}_{2}$ 透過度と透湿度の一覧}

\begin{tabular}{|c|c|c|c|c|}
\hline 試験体略称 & 中性化率 & $\begin{array}{c}\text { JASS5にたおける } \\
\text { 種類別中性化率 }\end{array}$ & $\begin{array}{c}\mathrm{CO}_{2} \text { 透過度 } \\
\left(\mathrm{mol} / \mathrm{m}^{2} \cdot 24 \mathrm{~h}\right)\end{array}$ & $\begin{array}{c}\text { 透湿度 }^{* *} \\
\left(\mathrm{~g} / \mathrm{m}^{2} \cdot 24 \mathrm{~h}\right)\end{array}$ \\
\cline { 1 - 2 } 薄塗E-1 & 0.49 & \multirow{2}{*}{1.02} & 2.28 & 173.6 \\
\hline 薄塗E-2 & 0.28 & & 2.53 & 119.3 \\
\hline 薄塗E-3 & 0.23 & & 0.31 & 133.4 \\
\hline 可とう薄E & 0.17 & 0.86 & 1.69 & 79.5 \\
\hline 防薄E & 0.10 & 0.68 & 1.15 & 26.7 \\
\hline 複層E & 0.26 & 0.22 & 0.47 & 96.6 \\
\hline 可とう複CE & 0.12 & 0 & 0 & 69.2 \\
\hline 防複E & 0.11 & 0.4 & 0.08 & 49.1 \\
\hline 塗料 & 0.15 & 0.64 & 0.32 & 82.3 \\
\hline
\end{tabular}

*JASS5にに記載8)、**前報吕において報告した值 


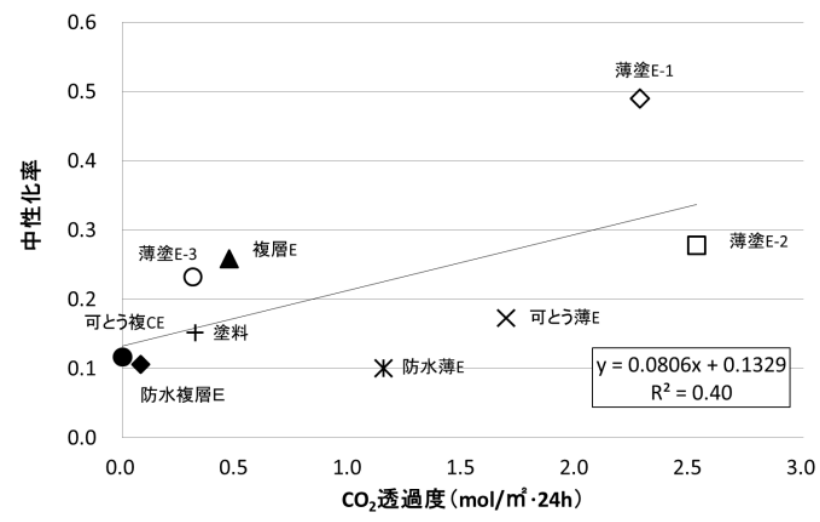

図 $3 \quad \mathrm{CO}_{2}$ 透過度と中性化率との関係

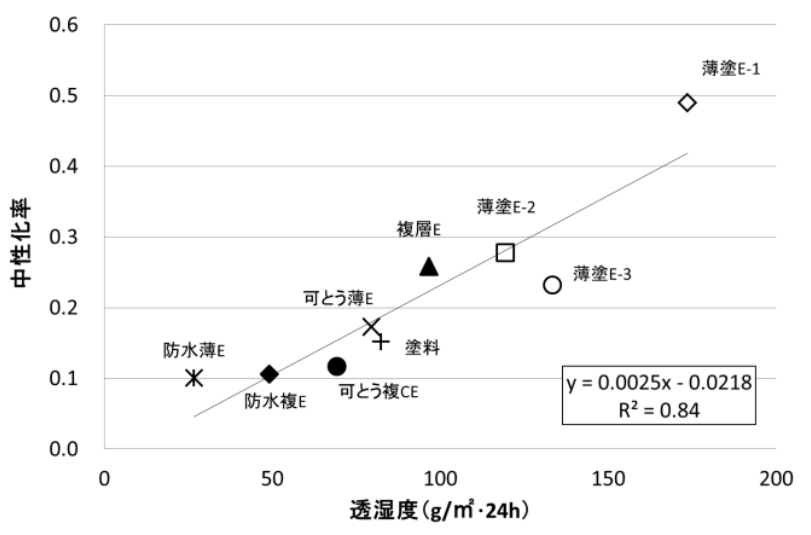

図 4 透湿度と中性化率との関係

これまでもコンクリートの中性化への影響として、湿度条件 ${ }^{9)}$ コンクリートの含水率および乾燥状態 ${ }^{10 \sim 12)}$ によって中性化抑制効 果に影響が出ることが報告されている。長谷川ら ${ }^{4)}$ は、仕上材の透 湿性の影響として含水率の保持があるとし、コンクリートの乾燥を 遅延することでコンクリートの中性化が抑制される期間が持続する としている。

\section{2 コンクリートの含水率の推移}

仕上材の $\mathrm{CO}_{2}$ 透過性と透湿性の中性化抑制効果への影響を明確に すべく、シリーズ 2 としてコンクリートの促進中性化試験を再び行 い、試験中のコンクリートの含水率の変化を確認した。

コンクリートの中性化深さの測定結果を表 6 に示す。シリーズ 1 とシリーズ 2 と同様の促進中性化試験を行ったため、図 5 にてデー 夕の比較を行った。全体的にシリーズ 2 は中性化率がやや低めとな る傾向を示した。ただし、データのばらつきは少なく、決定係数で 0.91 と誤差が小さく精度の高い実験であるといえる。

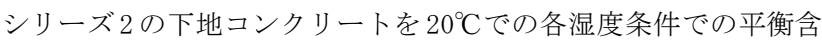
水率を表 7 に示す。この際、下地コンクリートは $100 \mathrm{~mm}$ 幅で割裂し、 側面以外をアルミテープでシールし恒温恒湿槽で養生した。含水率 の平衡の判定は重量変化の測定を行い、変化が収束してから 3 日後 に含水率を求め平衡含水率とした。各湿度条件とともに含水率が増 加することが確認できる。促進中性化試験と同じ相対湿度 $60 \%$ では、 含水率が 2.64 であった。
表 6 促進中性化試験の測定結果（シリーズ 2)

\begin{tabular}{|c|c|c|c|c|c|c|c|c|c|}
\hline \multirow{2}{*}{$\begin{array}{c}\text { 試験体 } \\
\text { 略称 }\end{array}$} & \multirow{2}{*}{$\begin{array}{c}\begin{array}{c}\text { 平均膜厚 } \\
(\mathrm{mm})\end{array} \\
\end{array}$} & \multicolumn{6}{|c|}{ 中性化深さ $(\mathrm{mm})$} & \multirow{2}{*}{$\begin{array}{l}\text { 速度係数 } \\
(\mathrm{mm} / \text { 週 } 1 / 2)\end{array}$} & \multirow{2}{*}{ 中性化率 } \\
\hline & & 1週 & 2週 & 4週 & 8週 & 13週 & 26週 & & \\
\hline 薄塗E-1 & 0.7 & 2.4 & 1.8 & 2.9 & 4.2 & 8.0 & 13.8 & 2.25 & 0.47 \\
\hline 薄塗E-3 & 0.5 & 1.2 & 0.9 & 1.2 & 1.5 & 2.7 & 5.6 & 0.87 & 0.18 \\
\hline 可とう薄E & 0.8 & 1.3 & 1.4 & 1.6 & 1.6 & 1.8 & 4.0 & 0.70 & 0.15 \\
\hline 防薄E & 0.5 & 1.2 & 1.2 & 1.5 & 1.3 & 1.3 & 2.9 & 0.54 & 0.11 \\
\hline 複層E & 0.7 & 1.4 & 1.4 & 1.8 & 1.7 & 2.2 & 4.5 & 0.78 & 0.16 \\
\hline 防複E & 0.5 & 1.2 & 1.2 & 1.2 & 1.3 & 1.7 & 3.4 & 0.59 & 0.13 \\
\hline 塗料 & 0.2 & 0.9 & 1.2 & 1.2 & 1.4 & 1.7 & 4.8 & 0.73 & 0.15 \\
\hline ブランク & - & 5.9 & 7.7 & 10.2 & 13.8 & 17.5 & 23.0 & 4.75 & 1.00 \\
\hline
\end{tabular}

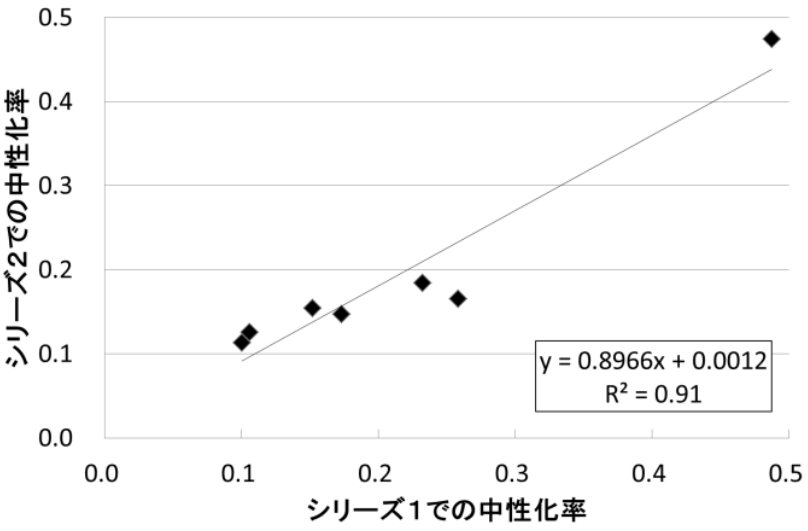

図 5 シリーズ 1 とシリーズ 2 の促進中性化試験における再現性確認

表 7 各湿度条件におけるコンクリートの平衡含水率

\begin{tabular}{|c|c|c|c|c|c|}
\hline 湿度条件(\%R.H.) & 60 & 70 & 80 & 90 & 98 \\
\hline 含水率(\%) & 2.64 & 2.78 & 3.02 & 3.10 & 3.14 \\
\hline
\end{tabular}

表 8 促進中性化試験における含水率の測定結果

\begin{tabular}{|c|c|c|c|c|c|c|}
\hline \multirow{2}{*}{ 試験体略称 } & \multicolumn{7}{|c|}{ 含水率 $(\%)$} \\
\cline { 2 - 7 } & 1週 & 2週 & 4週 & 8週 & 13週 & 26週 \\
\hline 薄塗E-1 & 3.74 & 4.30 & 4.02 & 3.86 & 2.97 & 2.95 \\
\hline 薄塗E-3 & 3.71 & 4.36 & 4.18 & 4.09 & 3.28 & 3.20 \\
\hline 可とう薄E & 3.70 & 4.22 & 4.12 & 4.11 & 3.22 & 3.15 \\
\hline 防薄E & 3.67 & 4.18 & 4.18 & 4.12 & 3.38 & 3.25 \\
\hline 複層E & 3.80 & 4.23 & 4.23 & 4.03 & 3.16 & 3.03 \\
\hline 防複E & 3.85 & 4.27 & 4.18 & 4.06 & 3.28 & 3.22 \\
\hline 塗料 & 3.60 & 4.02 & 3.90 & 3.86 & 3.15 & 3.11 \\
\hline ブランク & 3.50 & 3.80 & 3.88 & 3.72 & 2.75 & 2.64 \\
\hline
\end{tabular}

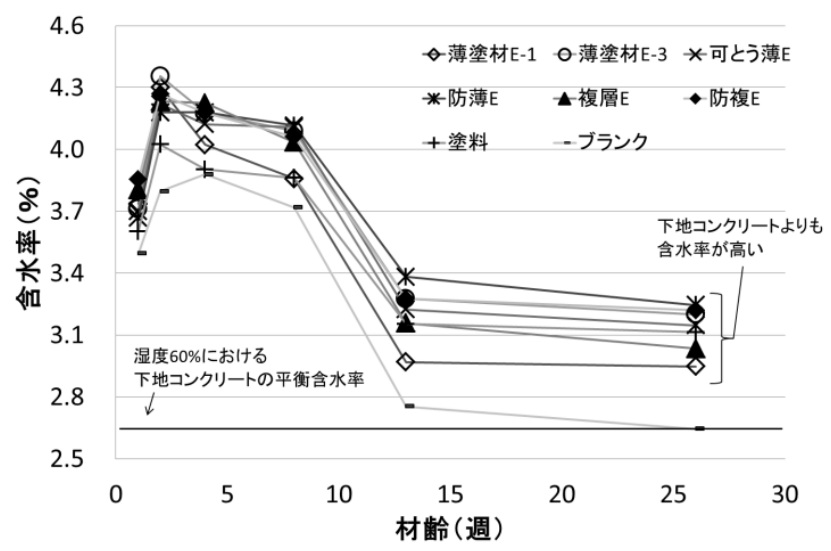

図 6 促進中性化試験における含水率の推移 


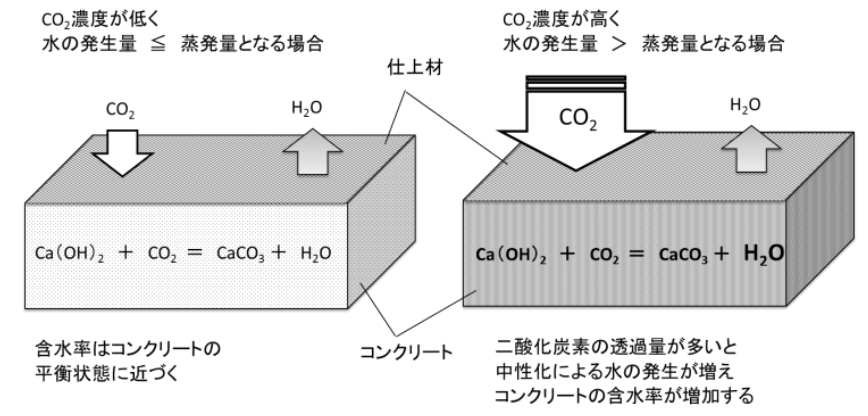

図 7 コンクリートの含水率増加のメカニズム

促進中性化試験におけるコンクリートの含水率の測定結果を表 8 に示す。またその推移を図 6 に示す。

仕上材を施したコンクリートの促進中性化試験の含水率は、試験 開始から急激に上昇していき、2 週目をピークに徐々に低下してい く。また、仕上材を施した試験体では全ての試験期間において含水 率が相対湿度 $60 \%$ の際のコンクリートの平衡含水率よりも高い状 態にあることが分かった。ブランクの試験体についても一度含水率 が上昇し時間とともに平衡含水率に達することが確認出来た。

既往の報告では、コンクリートの表面に透湿性の低い材料を施工 した場合、コンクリートの深部の水の影響をうけ、コンクリートの 表面含水率が上昇し中性化の進行が遅くなるとされているが、本検 討ではコンクリート全体の含水率が増加することが確認出来た。

通常、水蒸気などの気体は濃度勾配により拡散・浸透する方向が 決定され濃度の高い方から低い方へ移動する。湿度 $60 \%$ の平衡含水 率よりも高い含水状態のコンクリートからは乾燥方向への水蒸気の 移動が起こるはずで、外部から内部一の水分の移動は考えにくい。 水の発生経路として $\mathrm{CO}_{2}$ とコンクリートのアルカリ成分との中和反 応により生成する水分によってコンクリートの含水率が上がってい ると考えられる。促進中性化試験における含水率増加のメカニズム を図 7 に示す。

\section{3 透湿性が及ぼすコンクリートの含水率と中性化への影響}

図 6 をみると、中性化の進行が早く水和反応が多く進行している はずのブランクより、仕上材を施工してあるコンクリートのほうが 含水率は高い。また、材齢 1 週目から 2 週目の含水率の上昇幅も仕 上材を施工しているほうが大きいことがわかる。中和反応によって 生成された水は仕上材の透湿性によって蒸発が抑制された状態とな っていると考えられる。

仕上材の透湿度と材齢 26 週での含水率との関係を図 8 に示す。 決定係数で 0.56 と一定の相関を確認できる。含水率と中性化率との 関係についても同様に 0.64 と相関性が確認される。図 9 に示寸。そ の際、含水率が低くなるにつれ、中性化率の值にばらつきが大きく なる傾向がみられる。含水率が低い薄塗 $\mathrm{E}$ と複層 $\mathrm{E}$ は、 $\mathrm{CO}_{2}$ 透過度が それぞれ 2.28 と 0.47 である。含水率が低い場合、仕上材の $\mathrm{CO}_{2}$ 透 過度の影響を受けやすくなると考えられる。

$\mathrm{CO}_{2}$ 透過量と水分発生量の関係性の定量的な解析も試みたが、仕上 材を通して $\mathrm{CO}_{2}$ が透過し、コンクリート中へ浸透する過程。コンク リート中での $\mathrm{CO}_{2}$ とアルカリ成分の中和による水分の発生量と速度。 コンクリートから仕上材を通して水分が放散される過程が複雑に絡 み合っており解明には至らなかった。

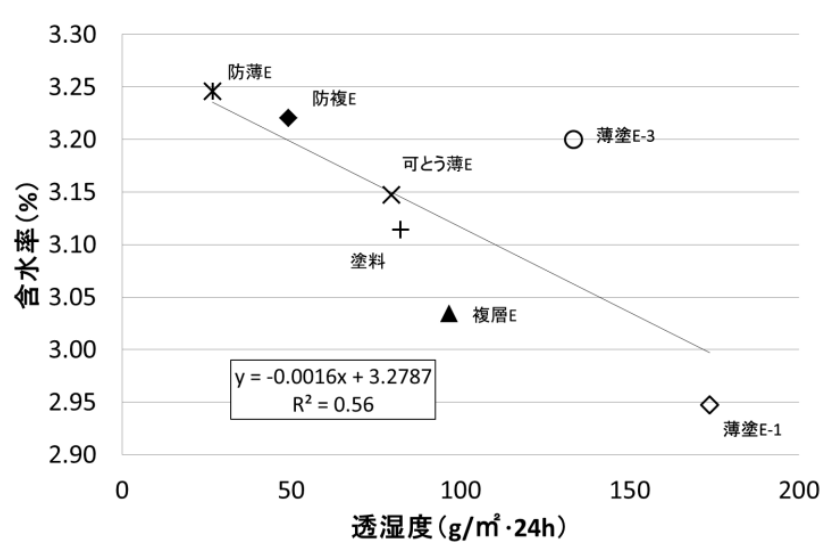

図 8 透湿度と含水率の関係（材齢 26 週で比較）

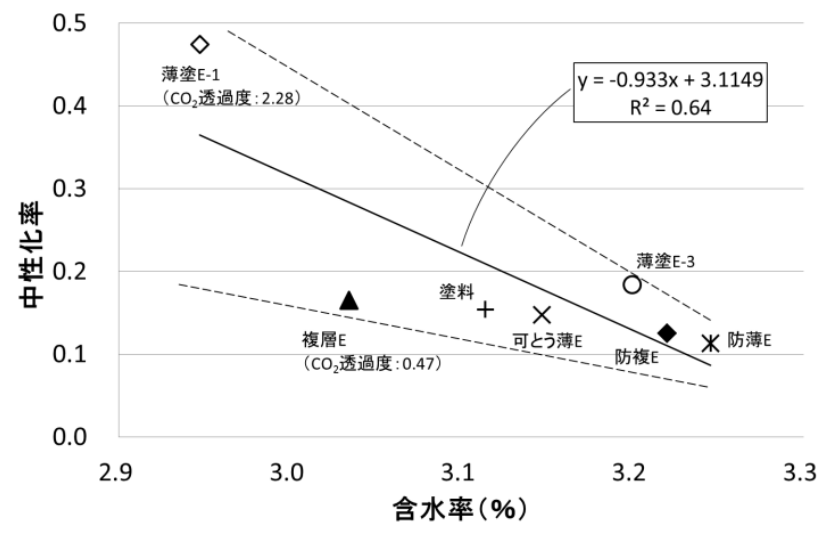

図 9 含水率と中性化率との関係

いずれにせよコンクリートの含水状態と中性化傾向および仕上材 の透湿性には密接な関係が見られる。ただし、透湿性は中性化抑制 効果と相関が直接あるのではなく、含水率の増減に関与し間接的に 中性化速度に影響を与えると考えられる。含水率の増加は、コンク リートの中和反応により発生する水の影響だと考えられる。

大気中の $\mathrm{CO}_{2}$ 濃度は凡そ 400 700ppm 程度であり、促進試験での $5 \%$ という $\mathrm{CO}_{2}$ 濃度の 1 万分の 1 程度の濃度である。当然、 $\mathrm{CO}_{2}$ 濃度 が低い場合はコンクリート中で発生する水分は少なくなり、コンク リートの含水率も標準状態に近い值に保たれるはずである。促進中 性化試験においては、透湿性が中性化試験との相関性を示寸が、屋 外暴露試験においては、仕上材の $\mathrm{CO}_{2}$ 透過度の影響を受けやすくな る可能性が高く今後の課題としたい。現在、我々は屋外暴露条件で の中性化試験も検討中であり、仕上材の $\mathrm{CO}_{2}$ 透過性および透湿性が 中性化抑制効果に与える影響をさらに解明していく予定である。

\section{4. まとめ}

仕上材の中性化抑制効果について、特に $\mathrm{CO}_{2}$ 透過性および透湿性 が与える影響について確認するため促進中性化試験を実施した。そ の検討結果は、以下のようにまとめられる。

(1) コンクリートの促進試験において、JIS 上は同じ種類に分類され るものでも、中性化率が $1 / 2$ になるものもある。現状、仕上材の 
中性化抑制効果のデータも少なく、製品ごとに中性化抑制効果を 評価する必要がある。

(2) $\mathrm{CO}_{2}$ 透過性及び透湿性のいずれが中性化深さと相関するかにつ いて促進中性化試験で検討した。その結果、仕上材の $\mathrm{CO}_{2}$ 透過性 より透湿性のほうが、コンクリートの中性化深さに影響を与える 結果となった。このメカニズムとして、中性化に伴い発生する水 の影響で特に中性化が進んでいる領域でのコンクリートの含水 率が増加することが確認できた。

（3）促進中性化試験において、仕上材を施したコンクリートの含水率 は仕上材なしのブランクの含水率よりも高く、また、同湿度にお ける同じ下地コンクリートの平衡含水率よりも高いことが確認さ れた。このような高含水率の領域では、コンクリートの中性化反 応は抑制される。このような理由で、仕上材の $\mathrm{CO}_{2}$ 透過性より透 湿性のほうが、コンクリートの中性化深さとの相関性が高いと考 える。

今後の課題として、屋外暴露試験や実際の使用条件下では促進中 化試験と比較して二酸化炭素濃度は著しく低いため、中性化反応に より生成する水はコンクリート含水率の変動に大きな影響は及ぼさ ないと考えられる。したがって、屋外暴露試験や実際の使用条件下 においてはコンクリート中性化深さと $\mathrm{CO}_{2}$ 透過性の間に相関性が認 められる可能性があり、この点についての検討を予定している。

\section{参考文献}

1）向井毅, 菊池雅史, 福田泰久, 宮本俊次 : 外装仕上材の躯体保護に関寸る 研究, 日本建築学会大会学術講演梗概集, pp. 353-354, 1986

2) 向井毅, 菊池雅史, 福田泰久: 外装仕上材の躯体保護性能および塗膜の透 湿性に関する実験的検討, 日本建築学会関東支部研究報告集, pp. 265-268, 1987

3）千歩修, 馬場明生, 小俣一夫, 松島泰幸: コンクリートの外装仕上げ材料 の躯体保護効果, 日本建築学会大会学術講演梗概集, pp. 609-610, 1989

4）長谷川拓哉, 千歩修, 大久保孝昭, 古賀純子 : 建築用仕上塗材の中性化に 関する研究, 日本建築学会構造系論文集第 609 号, pp. 23-30, 2006. 11

5）石崎貴之, 小山明男, 菊池雅史, 佐藤隆軌：仕上塗材の経年劣化を考慮 した RC 造建築物の中性化抑制効果に関する実験的研究 その 2 仕上塗材の 中性化抑制効果, 日本建築学会大会学術講演梗概集, pp. 317-318, 2010 6) 川村康晴, 本橋健司: 迅速な建築用仕上塗材及び塗料の二酸化炭素透過性 の評価方法，日本建築技術報告集第 43 号，pp. 825-830，2013.10

7）千歩修, 馬場明生, 松島泰幸, 小俣一夫 : 仕上げ塗材の躯体保護効果に関 する研究, 日本建築仕上学会大会論文集, pp. 49-52, 1990.10

8）日本建築学会：建築工事標準仕様書・同解説 JASS5 鉄筋コンクリート 工事, pp. 194-203, 2009

9）阿部道彦, 桝田佳寬, 田中斉, 柳啓, 和泉意登志, 友沢史紀: コンクリー 卜の促進中性化試験の評価に関する研究, 日本建築学会構造系論文報告集第 409 号, 1990 年 3 月

10）大岸左吉, 楊静: 促進法によるコンクリートの長期中性化推定の試み, セメント・コンクリート, No. 533, pp. 41-48, 1991

11）依田彰彦, 横室隆: コンクリートのケミカルレジスタンスに関する研究 (その 2 , 草津温泉水による浸漬したコンクリートについて), 日本建築学会 大会学術講演梗概集, pp. 191-192, 1983

12）申雪寒, 長谷川寿夫: コンクリートの乾燥程度を考慮した外断熱建物躯
体の中性化速度予測式の提案, コンクリート工学年次論文集 vol. 27, No. 1, pp625-630, 2005

[2015 年 10 月 6 日原稿受理 2015 年 11 月 9 日採用決定］ 